\title{
Translational research into gut microbiota: new horizons in obesity treatment
}

\section{Pesquisa translacional em microbiota intestinal: novos horizontes no tratamento da obesidade}

Daniela M. Tsukumo, Bruno M. Carvalho, Marco A. Carvalho-Filho, Mário J. A. Saad

Received in Feb/05/2009 / Accepted in Feb/15/2009.

Published Arq Bras Endocrinol Metab. 2009;53(2):139-44

The authors of the above manuscript would like to apologize and retract it because in some paragraphs there are verbatim and unquoted sentences from others texts, although most of them, but not all, have been referenced. A corrected version of this review will be available in the next volume of Arq Bras Endocrinol Metab.

This retraction confirm the integrity of papers published in Arq Bras Endocrinol Metab. 